\title{
On the genus Yangtzemerisma and related genera (Mollusca: Merismoconchia)
}

\author{
Yu Wen \\ Nanjing Institute of Geology and Palacontology, \\ Chinese Academy of Sciences, Nanjing, 210008 China. \\ Present address: Department of Earth and Planetary Sciences, \\ Western Australian Museum, 49 Kew St, Welshpool, \\ Western Australia 6106, Australia. Email: wen.yuamuseum.wa.govau
}

\begin{abstract}
Re-examination of the holotypes of the earliest Cambrian molluscs Yangtzemerisma rarum $\mathrm{Yu}, 1984$ and Merismoconcha multisegmentata Yu, 1979, revealed some new structures such as soft-bodied organs and the number and position of the dorsoventral locomotive muscle scars. This new information is added to previous knowledge of the form of the shell, the elongate-ovate aperture, the growth lines and reticulate sculpture. Together indicate that the Merismoconchia differs from all other classes of the Phylum Mollusca, consistent with their status as an independent molluscan class.
\end{abstract}

Key words: Mollusca, Merismoconchia, Yangtzemerisma, soft-bodied organs, earlierst Cambrian, Yangtze Platform, China.

\section{INTRODUCTION}

At present, the Merismoconchia is a small group of genera and species best known from the earliest Cambrian of China (Yu 1979, 1984a, 1984b, 1987b). However, they also occur in the Lower Cambrian "Herault" limestone of Montagne Noire, France (Kerber, 1988) and also perhaps in the Lower Cambrian Atdabanian Stage of the Kuznetsk Alatau, Siberia (Aksarina in Pospelov et al., 1995) and the Lower Cambrian Tommotian Stage of western Mongolia (Zhegallo, in Esakova and Zhegallo 1996) (Figure 1).

Although there is no living example that might help to confirm their position in the Phylum Mollusca, it is contended that merismoconchs exhibit some fundamental molluscan features, such as a single bilaterally symmetrical shell, one of the basic features of the phylum (Yochelson, 2000). The shell is elongate-ovate or spoon-shaped. The dorsal side of the internal mould is divided by anterior and posterior transverse interior shell costae into three unequal parts. The anterior part slightly protrudes to the adapical margin of the aperture, known as the rostrate segment. The second part is bordered by anterior and posterior intersegmental costae and is designated as the second segment, while the remaining posterior part is interpreted as the body segment. The transverse costae between the rostrate and second segments is named the anterior intersegmental furrow, whereas that between the second and the body segments is called the posterior intersegmental furrow. In some cases, both anterior and posterior intersegmental furrows extend laterally and converge gradually with each other to reach the anterior margin of the both left and right sides, forming a joint furrow, termed convergent furrow (Figures 2, 3).

So far as I am aware, most species of merismoconchs are preserved as internal moulds. Numerous traces of the growth lines, concentric ridges and radial ridges or lines can be seen on the internal moulds (Figures 4A, D; 5A, C, D, G, K, L), but specimens retaining external ornament are extraordinarily rare. Only one specimen is known to bear such sculpture. It was collected from the Huangshandong Member of the Tongying Formation at Huangshandong in Yichang, Hubei (NIGP 65025). As in other molluscan classes, the surface of the paratype of Yangtzemerisma rarum $\mathrm{Yu}, 1984$ is ornamented with fine growth lines and prominent concentric ridges, crossed by sharply radial ridges to form the reticulate sculpture, as shown in Figure 5H-J. In Merismoconcha? sp. of Kerber (1988) the rostrate and second segments also show the presence of growth lines and a reticulate sculpture (Kerber 1988, plate 6, figs 6, 7, 8, 10, 12a, $12 b, 15 a, 15 b)$. A shell with prominent growth lines is one of the basic features of the Mollusca (Yochelson 2000).

The aperture of the shell also demonstrates important molluscan characters. In Merismoconcha multisegmentata $Y u, 1979$, the ventral side of the 


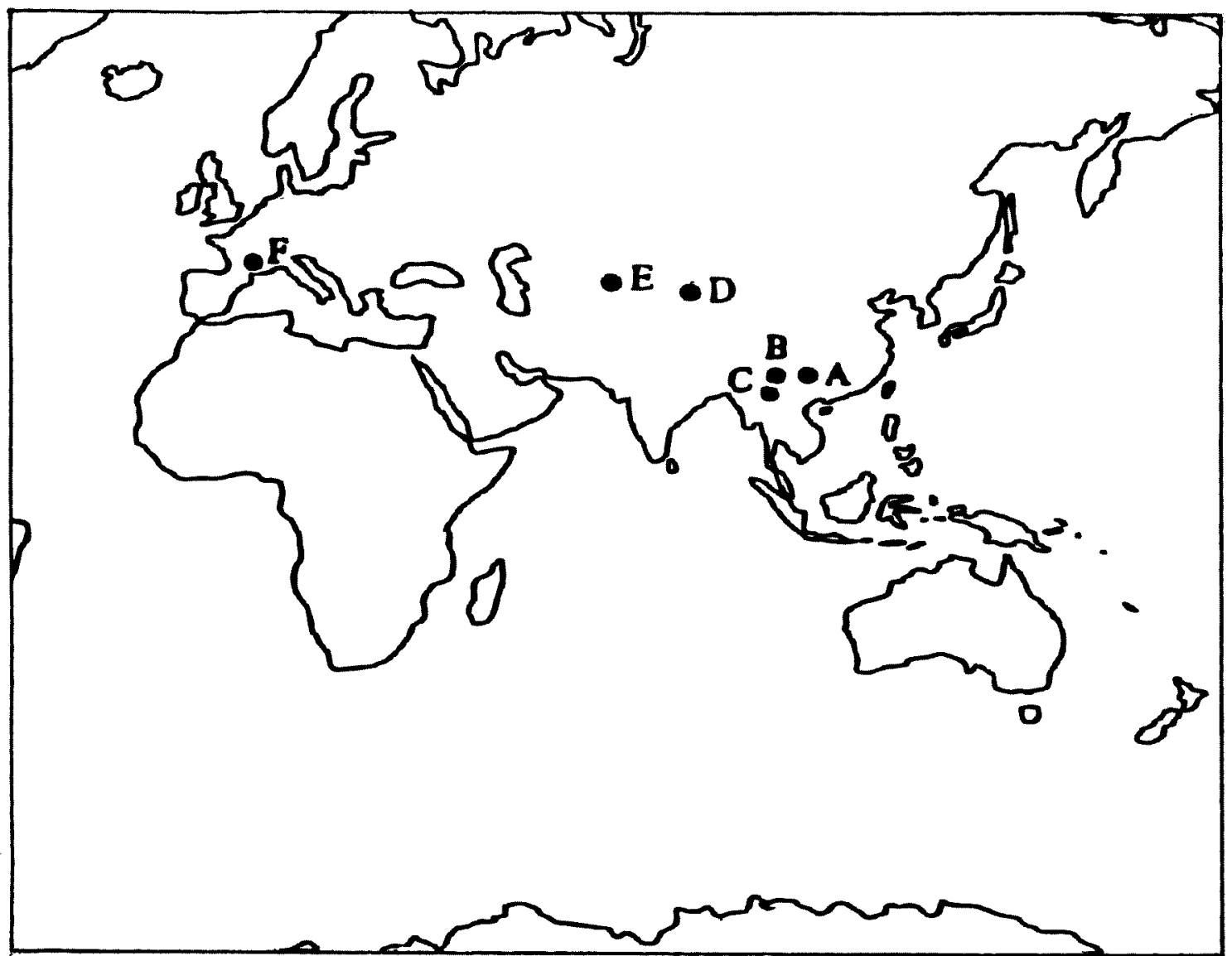

Figure 1 Sketch map showing the fossil localities. A. Yangtzemerisma rarum Yu, 1984. Yichang, W. Hubei, China. B. Merismoconcha multisegmentata Yu, 1979 Emei, Sichuan, China. C. Minymerisma yunnanense Yu, 1984. Xundian, E. Yunnan, China. D. Davidella tommotica Zhegallo, 1996. W. Mongolia. E. Kundatoides perplexus Aksarina, 1995. Kuznetsk Alatau, Siberia. F. Merismoconcha? sp. Kerber, 1988. Montagne Noire, France.

shell possesses an elongate-ovate aperture, and the apertural margin is simple, but slightly expanded (Figures 5F, 6G).

The muscle scars are another indication for the position of the Class Merismoconchia. The merismoconchs feature well-preserved muscle scars, which at present are only expressed on the internal mould. Since their body is divided into three unequal parts by two transverse, internal costae, their muscle scars are situated accordingly in different segments of the shell. The muscle scars are found at the second and body segments respectively. The number and arrangement of the muscle scars on the internal mould are similar to other classes of the Mollusca, especially the Class Tergomya (or living Monoplacophora). For example, Yangtzemerisma rarum has an arched, band-like muscle scar, situated at the middle part of the second segment (Figures 4A-H). In Merismoconcha multisegmentata, a pair of second segmental muscle scars are large and arched, tadpole-like in shape (Figures 3A; 5A, B, D, $E, G$; $6 F$ ). Based on the position of the second segmental muscle scars, they apparently played an important role in controlling the various activities inside the oral cavity and other functions. Therefore, the second segmental muscle scars may be equivalent to the set of radular muscle scars of the Class Tergomya. In the body segment of Yangtzemerisma rarum, twelve obscure pairs of dorsoventral locomotive muscle scars can be observed on both the left and right sides of the body segment (Figures 2, $4 \mathrm{~A}, \mathrm{~B})$.

Of special interest is the presence of apparent soft-bodied organs and soft-bodied tissues in the body segment of Yangtzemerisma rarum and Merismoconcha multisegmentata from the Lower Cambrian of Yangtze Platform, here reported for the first time. Generally speaking, soft-bodied fossils are usually found in mudstones or shales, such as the Lower Cambrian Chengjiang fauna and the Middle Cambrian Burgess Shale fauna. In other sedimentary environments such preservation is extremely rare (Fedonkin and Waggoner 1997). In Yangtzemerisma rarum and Merismoconcha multisegmentata, the top of the body segment bears a pair of glands, which are triangular in shape. From their size and location, they are inferred to be equivalent to the oesophageal glands of 
polyplacophorans (Fretter 1937; Hyman 1967; Salvini-Plawen 1985,1988 ) or the salivary glands of Odontogriphus omalus Conway-Morris, 1976 (Caron et al. 2006). A series of soft tissues along the outside of the dorsoventral locomotive muscle scars probably corresponds to the ctendium, nephridium or genital glands. Like the modern polyplacophorans Acanthopleurus echinatus (Barne, 1842) and Hanleya hanleyi (Bean, 1844) (Fretter 1937; Hyman 1967; Kaas and van Belle 1980; Salvini-Plawen 1988) and monoplacophorans Neopilina galatheae Lemche 1957, Vema ewingi Clarke and Menzies, 1959, Rokopella oligotropha (Rokop, 1972), Laevipilina hyalina McLean, 1979 and Micropilina arntzi (Wren and Hain, 1992) (Lemche and Wingstrand 1959; McLean 1979; Wingstrand 1985, Salvini-Plawen 1985, 1988; Haszprunar and Schaefer 1996; Schaefer and Haszprunar 1996; Wren and Gofas 1996), the intestine of Yangtzemerisma rarum is located in the posterior two-thirds of the body segment, mainly on the left side. It shows a number of narrowly rounded loops, which may run in a clockwise direction. The last loop ends in the rectum, which runs near the median line up to the anus (Figures 2, $4 \mathrm{~A}, \mathrm{~B}, \mathrm{I})$. A large gland surrounding the intestine is interpreted as a midgut glands. The new information provides further evidence that the Merismoconchia is an independent class of the Phylum Mollusca.

The specimens examined in this study are lodged in the Nanjing Institute of Geology and Palaeontology (NIGP), Chinese Academy of Sciences, Nanjing, China.

\section{SYSTEMATIC PALAEONTOLOGY}

\section{Class Merismoconchia Yu, 1983}

\section{Diagnosis}

Molluscs with a single, bilaterally symmetrical and metamerical shell.

\section{Order Merismoconchida Yu, 1979}

\section{Diagnosis}

Shell elongate-ovate, subelliptical, spoon-shaped or slightly arched, with external reticulate sculpture; interior of shell with two transverse shell costae, divided into three unequal parts: rostrate, second, and body segments, and having radular and dorsoventral locomotive muscle scars. Aperture elongate ovate or subelliptical.

\section{Superfamily Merismoconchioidea Yu, 1979}

\section{Diagnosis \\ Same as for the order.}

\section{Family Merismoconchidae Yu, 1979}

\section{Diagnosis}

Shell minute, elongate ovate, spoon-shaped or slightly arched, divided internally into rostrate, second and body segments by anterior and posterior transverse internal costae. Aperture elongate ovate. Surface ornamented with growth lines and reticulate sculpture and with scars of the radular and dorsoventral locomotive muscles.

\section{Remarks}

In this family have been included the genera Minymerisma Yu, 1984 from the Lower Cambrian Zhongyicun Member of Yuhucun Formation in eastern Yunnan, Yangtzemerisma Yu, 1984 from the Lower Cambrian Huangshandong Member of Tongying Formation in western Hubei and Merismoconcha Yu, 1979 from the Lower Cambrian Maidiping Member of Hungchunping Formation in Sichuan. In addition, the genera Kundatoides Aksarina, 1995 from the Lower Cambrian Atdabanian Stage of Kuznetsk Alatau, Siberia and Davidella Zhegallo, 1996 from the Lower Cambrian Tommotian Stage of western Mongolia possibly should be added, based on general morphological features of the material (moulds).

\section{Subfamily Yangtzemerismatinae Yu, 1987}

\section{Genus Minymerisma Yu, 1984}

Minymerisma Yu, 1984b: 439, 445; Yu, 1987b: 135; Bengtson, 1992: 1028; Sepkoski, 2002: 78, 468.

\section{Type species}

Minymerisma yunnanense $Y u, 1984 b$, by original designation, from Lower Cambrian Zhongyicun Member of Yuhucun Formation, at Baizai of Xundian, eastern Yunnan, China.

\section{Diagnosis}

Minute, narrowly elongate, spoon-shaped or slightly arched. Dorsal side of internal mould divided internally into three unequal parts by anterior and a posterior transverse shelly costae: rostrate segment short and lenticular, strongly protruding to adapical margin of aperture; second segment long and arched, while body segment convex, occupying about half length of shell. Aperture elongate-ovate. Surface covered with concentric rugae, radial striae and growth lines. Other internal structures including muscle scars unknown.

\section{Remarks}

In dorsal view, this genus resembles Yangtzemerisma Yu, 1984, but differs from the latter in the narrower dorsal side, the longer and more arched second segment and in the shorter 
body segment. This genus also resembles Merismoconcha Yu, 1979 in some aspects, but can be easily distinguished from Merismoconcha by the more arched second segment, the shorter body segment and by the different position of the convergent furrow.

\section{Minymerisma yunnanense $\mathrm{Yu}, 1984$}

Figures 3B, 5 K-L, 6 C

Minymerisma yunnanense Yu, 1984b: 439, 445; plate II, figures 1-2, text-figure 6; Yu, 1987b: 136, plate
21, figures 1-3, text-figure 45; Yu, 1990: 158, plate 5, figures 9-10.

\section{Material examined}

\section{Holotype}

NIGP 65026, collection of the Nanjing Institute of Geology and Palaeontology, Chinese Academy of Sciences. Collected by the author and his colleagues in 1980 from the Lower Cambrian Zhongyicun Member of the Yuhucun Formation, at Baizai of Xundian, eastern Yunnan.

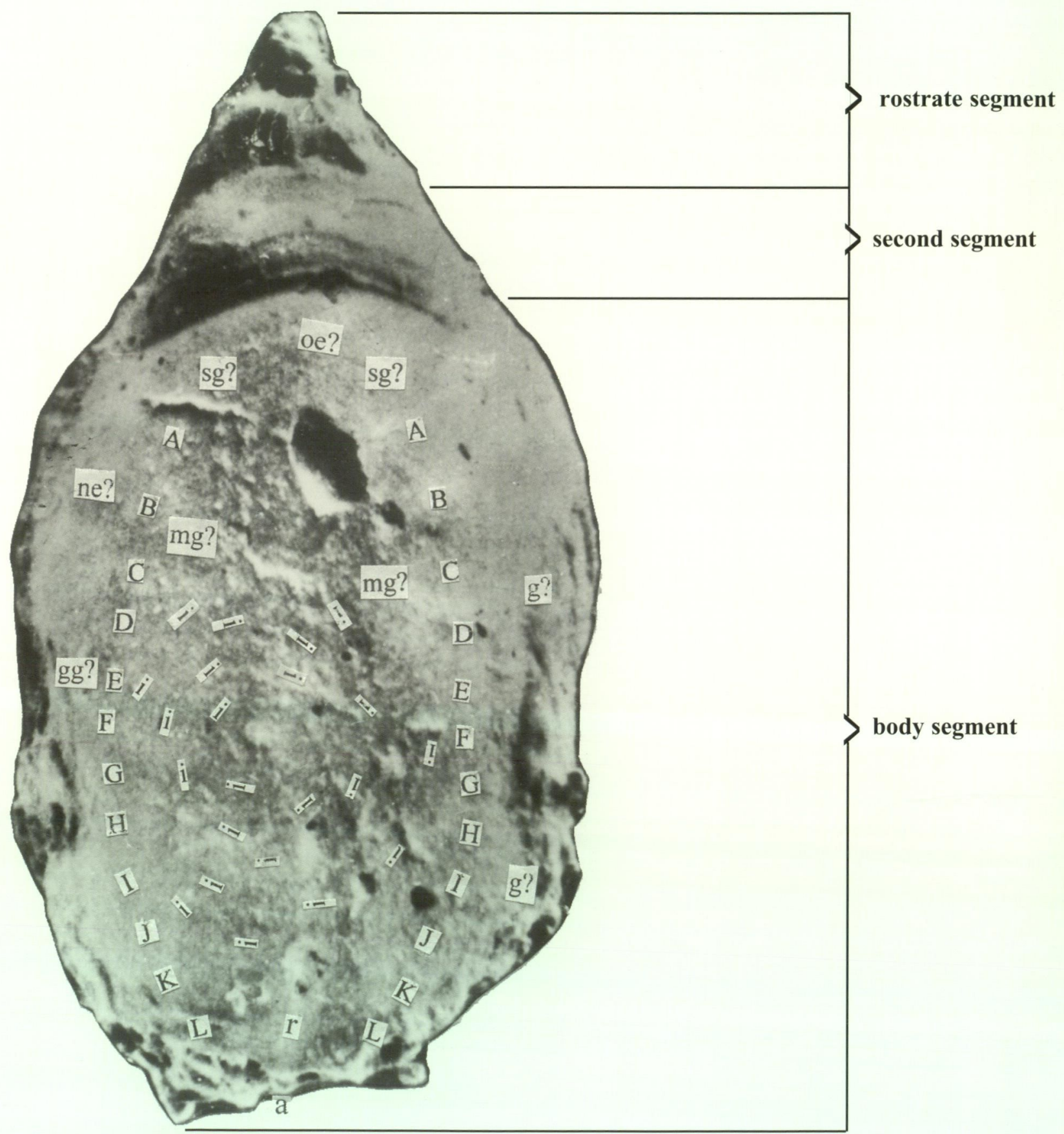

Figure 2 Yangtzemerisma rarum Yu, 1984, NIGP 65022. Dorsal view, x 90, showing muscle scars and soft-bodied organs. Abbreviation: A-L, dorsoventral locomotive muscle scars; a, anus; g, ctendium (?); gg, genital gland (?); i, intestine: $\mathrm{mg}$, midgut gland; ne, nephridium (?); oe, oesophagus; $r$, rectum; sg, salivary glands (?). 


\section{Paratype}

NIGP 65027, from the same locality and horizon as the holotype.

\section{Description}

Minute, slightly arched, spoon-shaped; dorsal side arched and narrowly rounded, abruptly sloping to abapical margin of aperture. Rostrate segment short and lenticular in lateral view, occupying about one-tenth shell length, strongly protruded forward to adapical margin, with an obtusely rounded apex. Second segment long and strongly arched, occupying about one-third length of shell, maximum height near posterior intersegmental furrow. Body segment longer and wider than other segments, slopes steeply toward posterior end. Anterior intersegmental furrow fine and shallow, starting from dorsal side, extending nearly straight for about two-thirds total height of lateral side and then curved slightly forward to ventral side. Posterior intersegmental furrow wide and concave, sloping towards anterior end and convergent with anterior one on upper part of the adapical margin of aperture. Aperture elongateovate.

Surface covered with numerous concentric rugae, which are twelve in number on the second segment and up to sixteen on body segment, crossed by radial rugae to form a reticulate sculpture, as shown in figure $5 \mathrm{~K}$. Interspaces between concentric rugae covered with fine growth lines running parallel to the concentric rugae on left and right sides. Internal structures and muscle scars unknown. The holotype is $0.80 \mathrm{~mm}$ long, $0.48 \mathrm{~mm}$ high and $0.30 \mathrm{~mm}$ wide.

\section{Occurrence}

Zhongyicun Member of the Lower Cambrian Yuhucun Formation at Baizai of Xundian, eastern Yunnan. China.

\section{Genus Yangtzemerisma Yu, 1984}

Yangtzemerisma $\mathrm{Yu}, 1983$; 1572; Yu, 1984a: 21; Yu, 1984b: 444; $Y u, 1985: 401 ; Y u, 1987 b: 132 ;$ Bengtson, 1992: 1028; Sepkoski, 2002: 78, 554.

\section{Type species}

Yangtzemerisma rarum Yu, 1984: 444, by original designation; from Lower Cambrian Huangshandong Member of Tongying Formation, at Huangshandong of Yichang, western Hubei, China.

\section{Emended diagnosis}

Shell minute, elongate-ovate, spoon-shaped. Interior of shell with anterior and posterior transverse shelly costae, dividing dorsal side into three unequal segments: rostrate segment slightly protruded to adapical margin of aperture; second segment wide and rather arched, with a band-like muscle scar; body segment longer, broadly oval with twelve pairs of symmetrically arranged, metameric dorsoventral locomotive muscle scars. A rather wide and concave, median dorsal furrow is in centre of body segment together with some transverse, obliquely curved ridges on each side of median dorsal furrow. Aperture elongate-ovate. Surface covered with growth lines and reticulate sculpture.

\section{Remarks}

In the general form of the shell and concentric ridges, this genus is most closely related to Merismoconcha Yu, 1979. However, there are obvious differences between them: 1) In Yangtzemerisma, the second segment is more convex and longer, occupying about one-ninth the length of the shell, and with an arched, band-like muscle scar, while in Merismoconcha, the second segment is notably narrow and concave, occupying about one-twentieth the length of the shell and with a pair

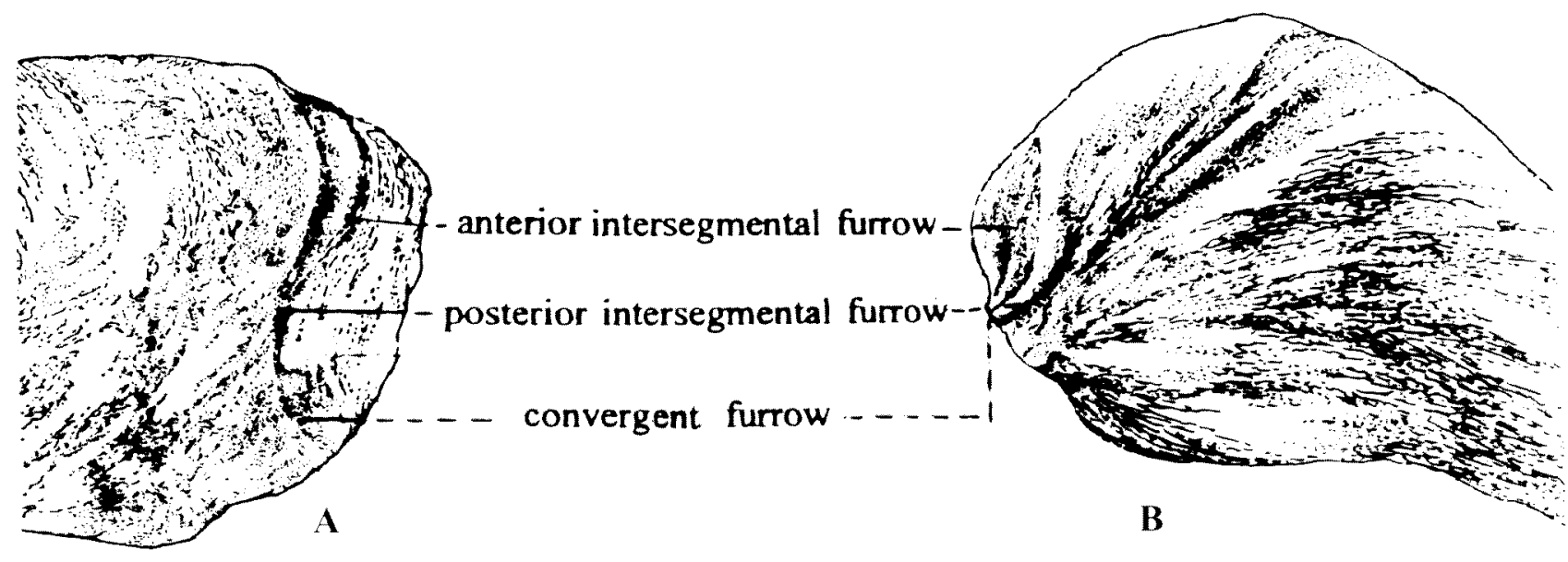

Figure 3 A. Merismoconcha multisegmontata Yu, right lateral view, x 66. B. Minymerisma yunnanense Yu, 1984, left lateral view, $\times 104$. 
Yu, W.

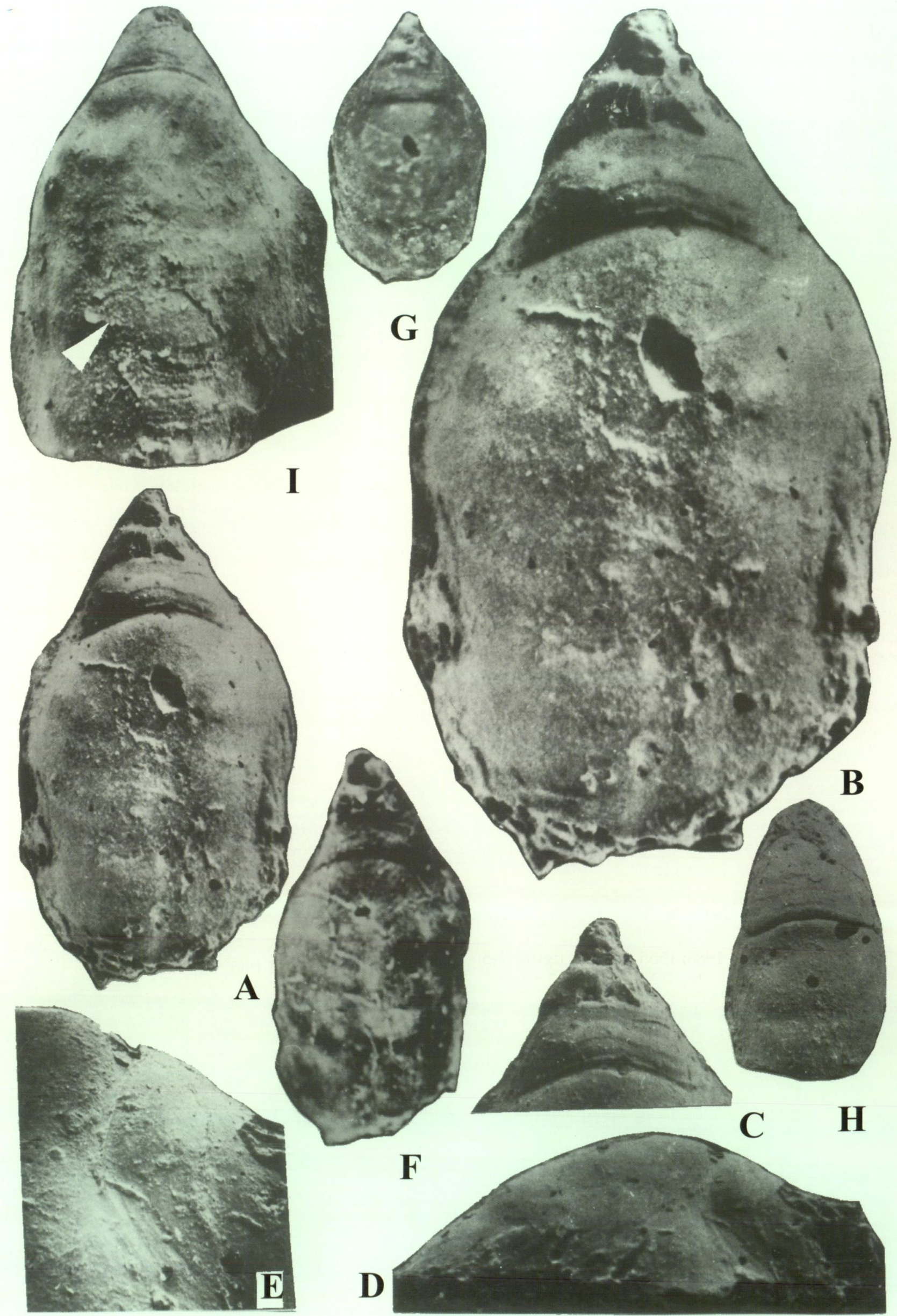


of tadpole-like muscle scars. 2) In Yangtzemerisma, the body segment is broadly oval, occupying about two-thirds the length of the shell, but in Merismoconcha, the body segment is elongate-oval, occupying nine-tenths the length of the shell. 3) In Yangtzemerisma, the surface is covered with strongly reticulate sculpture, whereas, the reticulate sculpture in Merismoconcha is finer.

In its tripartite shell and metameric muscle scars of the body segment, Yangtzemerisma is also similar to Kundatoides Aksarina, 1995 (Aksarina in Pospelov et al., 1995) from the Lower Cambrian Atdabanian Stage of Kuznetsk Alatau, Siberia. However, great differences between Yangtzemerisma and Kundatoides exist: 1) In Yangtzemerisma, the rostrate segment is very long and gradually tapering anterior, whereas in Kundatoides, the proarea is small and short. 2) In Yangtzemerisma, the second segment is broadly convex and has a raised band-like muscle scar, while in Kundatoides, the median part features a pair of rounded lobes. 3) In Yangtzemerisma, the body segment is broadly oval and has twelve pairs of locomotive muscle scars and a rather wide median dorsal furrow. In Kundatoides, the body part features a sharply median dorsal furrow and transverse ridges. The median dorsal furrow slightly widens towards the abapical margin and divides the body part into two nearly symmetrical parts. The transverse ridges are disposed on the each side of the median dorsal furrow and between the ridges there are more than four pairs of metameric, transverse-oval muscle (?) scars.

\section{Yangtzemerisma rarum $\mathrm{Yu}, 1984$}

Figures 2, 4A-I, 5H-J, 6A

Yangtzemerisma rarum Yu, 1984a: 32, plate II, figures 1-2; Yu, 1984b: 444, plate I, figures 1-10, plate II, figures 3-8; text-figures $1 \mathrm{a}, \mathrm{b}, 2 \mathrm{~b}$; $\mathrm{Yu}$, 1987a: 53, plate 2, figures 1-4; Yu, 1987b: 133, plate 19, figures 1-11, plate 20 figures 1-5, textfigure 17, 18b; Yu, 1988: 1555, plate 1, figure 3-5; Yu, 1989: 237, figure 1c-d; Yu, 1990: 143, plate 5, figures 1-6; Yu, 1996a: 433; 2005: 773.

Yangtzemerisma? cancellata Yu, 1984b: 445, plate II, figures 6-8; Yu, 1987b: 134, plate 21, figures 4-6.

\section{Material examined}

Holotype

NIGP 65022, collection of the Nanjing Institute of Geology and Palaeontology, Chinese Academy of Sciences. Collected by the author and his colleagues in 1980 from the Lower Cambrian Huangshandong Member of the Tongying Formatiom, Huangshandong of Yichang, western Hubei, China.

\section{Paratype}

NIGP 65023-65025, from the same locality and horizon as the holotype.

\section{Description}

Holotype is a well-preserved internal mould. It is minute, spoon-shaped, narrowly elongate in apical view, much longer than wide, with a narrow adapical margin and a broadly rounded abapical margin. Dorsal side broadly rounded, maximum height about one-third distance from posterior intersegmental furrow to abapical margin, then gradually sloping to posterior end; divided by two internal shell costae into three unequal parts: rostrate segment short, gently convex, lateral sides straight and slowly tapering toward anterior end. Second segment short and rather convex, occupying about one-ninth length of shell, and defined by anterior and posterior intersegmental furrows. Anterior intersegmental furrow is a fine and shallow arc, curved, and sloping, and reaching to anterolateral margin of shell; posterior intersegmental furrow wider and deeper than anterior, central portion of arc curved and parallel to anterior portion, then spreading gradually, sloping and bending forward to form a semicircular, narrowly marginal edge, before gradually sloping and reaching toward anterolateral margin. Body segment large and elongate, more than two-thirds length of shell, widely rounded, laterally broadly arched, gradually sloping to posterior end. Posterior margin broadly rounded. A rather wide and concave median dorsal furrow in centre of body segment occupies about one-sixth width of dorsum, starting at about 0.03 $\mathrm{mm}$ from posterior intersegmental furrow and extending to posterior end, and with a number of transverse, obliquely curved ridges on each side of

Figure 4 A-1. Yangtzemerisma rarum Yu, 1984. A. dorsal view, x 50. B. dorsal view, showing muscle scars, intestine and other soft-bodied organs and tissues, $x 90$. C. dorsal view, showing radular muscle scar, $x 60$. D. right lateral view, showing anterior and posterior intersegmental furrows, $x 45$. E. Detail of radular muscle scar, $x$ 100. F. dorsal view, showing soft-bodied tissues, $x 37.5$. G. dorsal view, showing transverse, obliquely curved ridges on each side of the median dorsal furrow, $x 25$. Holotype NIGP 65022 . H. dorsal view of an incomplete specimen, showing traces of radular muscle scar, $x$ 40. NIGP 65024. I. dorsal view, showing intestine (white arrow), dorsoventral locomotive muscle scars and other structures, $\times 130$. NIGP 65023. Lower Cambrian Huangshandong member of Tongying Formation, Huangshandong of Yichang, W. Hubei 
Yu, W.

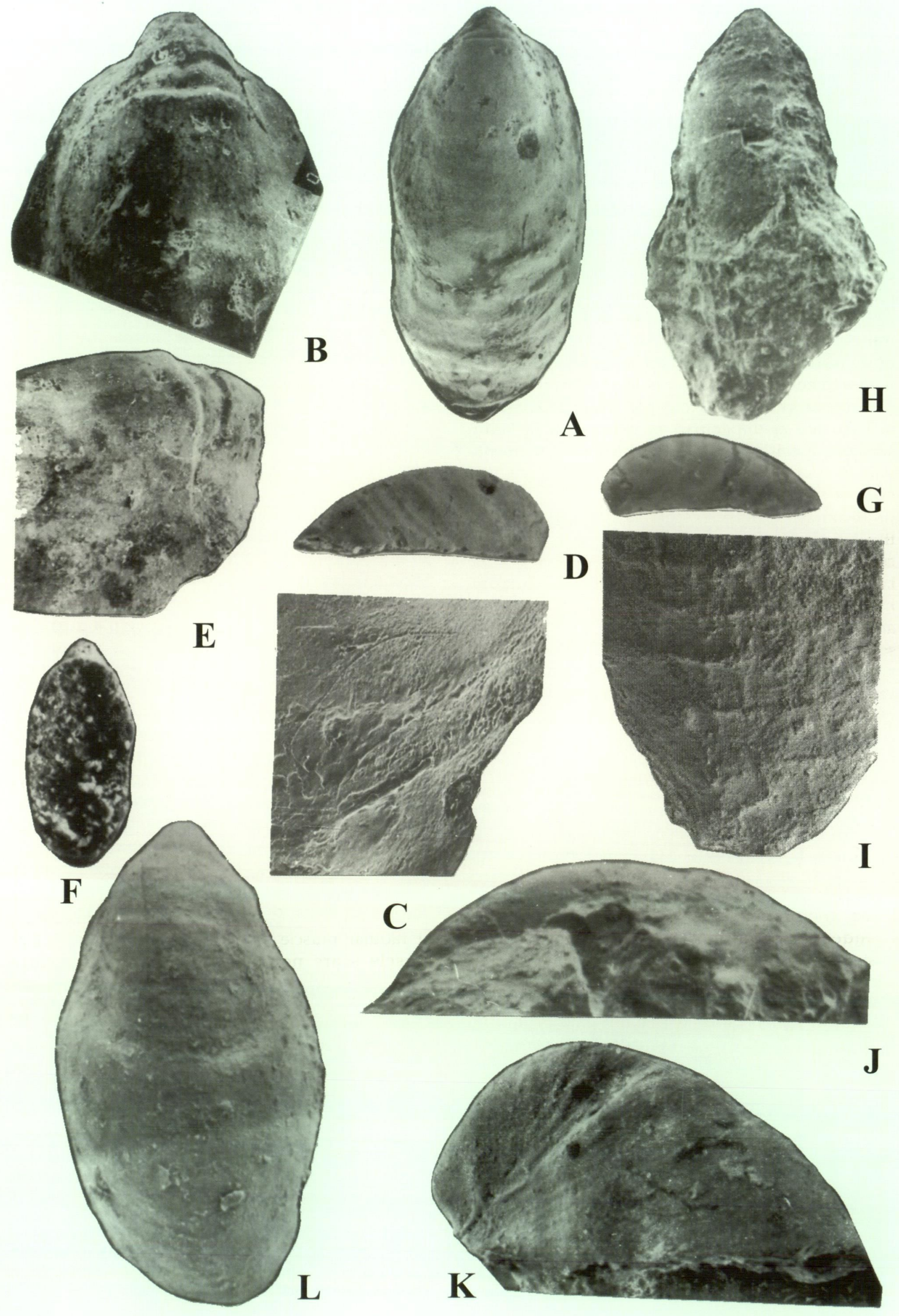


median dorsal furrow, which on left side are clearer than on right side.

Muscle scar in second segment corresponds large, simple, raised and band-like, situated in the middle part of second segment. Central portion of raised band-like muscle scar rather arched, with both sides gently convex, sloping toward lateral margins (Figures $4 \mathrm{~A}-\mathrm{G}$ ). In some specimens, arched bandlike radular muscle scar is not well-preserved, but traces or striae can be observed (Yu, 1987b, pl. 19, figures 8-11; pl. 20, figures 1, 2, 4; Figure 4H). Body segment with twelve pairs of metameric dorsoventral locomotive muscle scars symmetrically arranged on both sides of median dorsal furrow near lateral margins. A pair of dorsoventral locomotive muscle scars subcircular, located at about one-sixth of body segment length from posterior intersegmental furrow. Morphological feature of B-L pairs of scars are similar to A pair. Pairs B-D of scars are situated at upper part of mid-length of body segment. E pair is located at mid-length of segment. Pairs F-L of the scars situated in posterior of body segment (Figures 2, 4 A, B, F, G).

On top of dorsoventral locomotive muscle scars there is a pair of soft tissues, subtriangular in shape, consisting of many microspherical glandules. This is tentatively interpreted as the salivary gland. Intestine makes several narrowly rounded loops and is situated at posterior two-thirds of body segment, mainly on left side, and which may run in a clockwise direction. Last loop ends in rectum, which runs near median line up to anus ( $\mathrm{Yu}, 1987 \mathrm{~b}$, pl. 20, figure 1; Figures 2, 4A, B, I). Large "glands" surrounding the intestine are interpreted as midgut glands. A series of impressions of soft tissues along the outside of the dorsoventral locomotive muscle scars probably represent the ctendium, nephridium or genital gland.

Figure $5 \mathrm{H}-\mathrm{J}$ shows a partly preserved specimen with delicate ornament. The shell is rather thick, narrowly elongate, spoon-shaped, divided into three unequal segments. Dorsal side broadly rounded, gradually sloping to anterior and posterior ends respectively. Surface ornamented by equally spaced concentric ridges, radial ridges and growth lines. Concentric ridges prominent and strong, crossed by thick radial ridges to form a reticulate sculpture, growth lines fine as shown in Figure $5 \mathrm{H}-\mathrm{I}$.

\section{Measurements (in $\mathrm{mm}$ )}

NIGP 65022: length 1.50; height 0.55; width 0.80 NIGP 65023: length 1.00; height 0.50 ; width 0.70 NIGP 65024: length 0.90; height 0.55; width 0.40 NIGP 65025: length 2.40; height 1.25; width 0.90

\section{Occurrence}

Huangshandong Member of the Lower Cambrian Tongying Formation, at Huangshandong of Yichang, western Hubei, China.

\section{Subfamily Merismoconchinae Yu, 1987}

\section{Genus Merismoconcha Yu, 1979}

Merismoconcha, Yu 1979: 257, 266; He in Yin et al., 1980: 158; Yu, 1983: 1572; Yu, 1984a: 27; Yu, 1984b: 440, 445; Yu, 1987b: 137; Kerber, 1988: 168; Peel, 1991: 46; Bengtson, 1992: 1028; Sepkoski, 2002: 78, 465 .

\section{Type species}

Merismoconcha multisegmentata Yu, 1979, by original designation; from Lower Cambrian Maidiping Member of the Hungchunping Formation, at Gaoqiao of Emei, Sichuan, China.

\section{Diagnosis}

Minute, narrowly elongate, spoon-shaped. Dorsal side of internal mould divided into three unequal parts by two transverse costae: rostrate segment short, slightly protruded to adapical margin of aperture; second segment narrow and slightly concave, lenticular in dorsal view, gently restricted laterally; body segment elongate-ovate. Surface ornamented with concentric rugae, radial ridges or lines and growth lines. Second segment bears pair of radular muscle scars. Dorsoventral locomotive muscle scars not known in detail. Aperture elongate-ovate.

Figure 5 A-G. Merismoconcha multisegmentata $Y u, 1979$. A. dorsal view, showing radular muscle scars and sculptures, $\times 33$. B. Detail of radular muscle scars and salivary glands? $\times 65$. C. Detail of growth lines and reticulate sculptures, $x$ 130. D. right lateral view, showing the concentric rugate, $x 24$. E right lateral view, showing anterior and posterior intersegmental furrows and convergent furrow, $x$ 50. F. apertural view, showing shape of the aperture, x 25. G. left lateral view, x 21. Holotype NIGP 54465 . Lower Cambrian Maidiping Member of Hungchuping Fomaion, Gaugiao of Emei, Sichuan. H-J. Yangtzemerisma rarum Yu, 1984. H. dorsal view, showing the growth lines and reticulate sculptures $x 30$. 1. Detail of the growth lines and reticulate sculptures, $x$ 75. I. left lateral view, x 33. paratype NIGP 65025. Lower Cambrian Huangshandong Member of Tongving Formation, Huangshandong of Yichang, W. Hubei. K-L. Minrmerisma vunnanense $\mathrm{Yu}, 1984$. K. left lateral view, showing anterior and posterior intersegmental furrows and convergent furrow, growth lines, and reticulate sculpture, $x$ 90. L. dorsal view, showing concentric rugae, $x$ 110. Lower Cambrian Zhongyicun Member of Yuhucun Formation, Baizai of Xundian. E. Yunnan. 


\section{Remarks}

In lateral view, this genus appears to closely resemble Yangtzemerisma Yu, 1984. However, it differs in its more concave and narrower second segment, and in having a pair of radular muscle scars.

\section{Merismoconcha multisegmentata Yu, 1979} Figures 3A, 5A-G, 6F-G

Merismoconcha multisegmentata Yu, 1979: 258, 266, plate IV, figures 1-5, text-figure 8; He in Yin et al., 1980: 158, plate 13, figures 21-23; plate 14, figures 4, 5. non plate 13, figures 13-15; $\mathrm{Yu}$, 1984a: 32, plate I, figures 10-12; Yu, 1984b: 440, 445, plate III, figures 1-6; Yu, 1987a: 53, plate 2, figures 5-8; Yu, 1987b: 138, plate 22, figures 1-6; text-figure 18a; Kerber, 1988: 168; Yu, 1988: 1555; Yu, 1989: 237; Yu, 1990: 143, plate 5, figures 1114; Yu, 1993: 236, text-figure 16a; Yu, 2005: 773.

\section{Material examined}

\section{Holotype}

NIGP 54465, collection of the Nanjing Institute of Geology and Palaeontology, Chinese Academy of Sciences. Collected by the author and his colleagues in 1977 from the Lower Cambrian Maidiping Member of the Hungchunping Formation, at Gaoqiao of Emei, Sichuan, China.

\section{Description}

Minute, $2.20 \mathrm{~mm}$ length, $0.70 \mathrm{~mm}$ high, 1.00 $\mathrm{mm}$ wide, and $1.80 \mathrm{~mm}$ apertural length; narrowly elongate, spoon-shaped. Dorsal side convexly rounded, divided into three unequal segments by anterior and posterior internal shell costae: rostrate segment short, subtriangular in shape, strongly protruding forward to adapical margin of aperture; second segment narrower than rostrate and body segments, occupying about one-twentieth length of shell, lenticular, slightly concave, gently restricted laterally and bordered by anterior and posterior intersegmental furrows. Anterior and posterior intersegmental furrows spread laterally and converge in middle part of lateral parts, and have a convergent furrow gradually sloping toward anterior margin of aperture; body segment elongate-ovate, occupying more than nine-tenths length of shell.

Surface covered with concentric rugae, radial lines and growth lines. Concentric rugae not prominent, with about fifteen on the body segment; radial lines obscure, but with reticulate sculpture visible on posterior part of body segment (Figure 5 A, C)

Paired radular muscle scars large and simple, situated in middle part of second segment, occupying almost entire lenticular area. Muscle scars rather arched, tadpole-like, convexly rounded in central portion, then gradually sloping to both sides. In the body segment, there is a pair of supposed salivary glands on top of body segment as in Yangtzemerisma. Behind the supposed salivary glands is a pair of muscle scars (?), which is subelliptical in shape (Figure 5B).

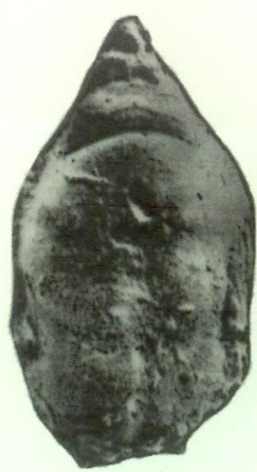

A

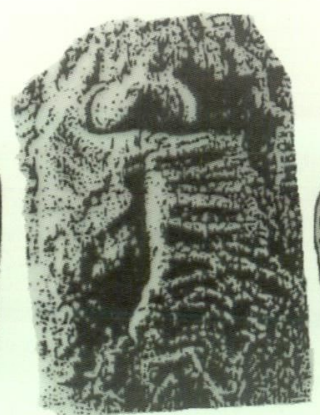

B

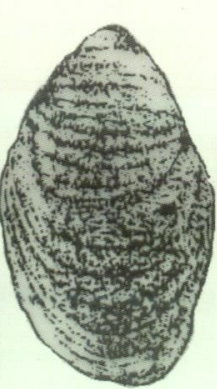

C

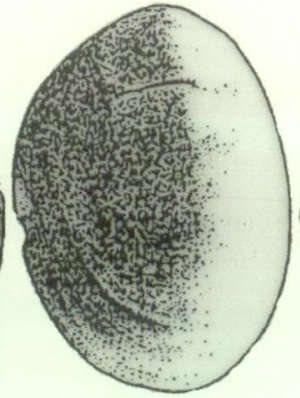

D

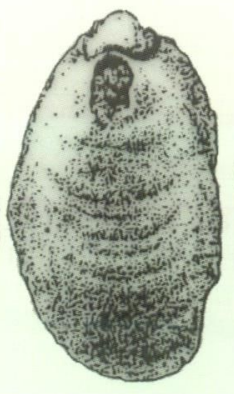

$\mathbf{E}$

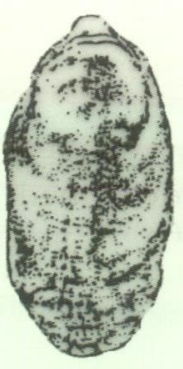

F

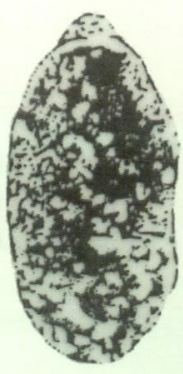

G

Figure 6 Diagram illustrating close similarities among the Lower Cambrian merismoconchids. A.Yangtzemerisma rarum Yu, 1984, x 23, NIGP 65022. Lower Cambrian Huangshandong Member of Tongying Formation, Huangshandong of Yichang, W. Hubei. B. Kundatoides perplexus Aksarina, 1995, x 7. Lower Cambrian Atdabanian Stage of Kuznetsk Alatau, Siberia (after Aksarina in Pospelov et al., 1995). C. Minymerisma yunnanense Yu, 1984, x 45. NIGP 65026. Lower Cambrian Zhongyicun Member of Yuhucun Formation, Baizai of Xundian, E. Yunnan. D. Davidella tommotica Zhegallo, 1996, x 37. Lower Cambrian Tommotian Stage of W. Mongolia (after Zhegallo in Esakova and Zhegallo, 1996). E. Merismoconcha? sp. Kerber, x 14. Lower Cambrian "Herault" limestone, Montagne Noire, France (after Kerber, 1988). F-G. Merismoconcha multisegmentata Yu, 1979, x 18.5, NIGP 54465. Lower Cambrian Maidiping Member of Hungchuping Formation, Gaoqiao of Emei, Sichuan, China. 


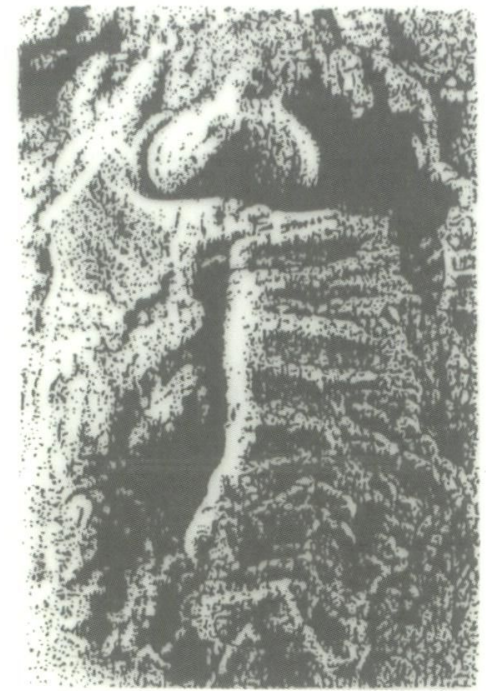

Figure 7 Kundatoides perplexus Aksarina, 1995. Apical view, $x$ 11. Lower Cambrian Atdabanian Stage of Kuznetsk Alatau, Siberia (after Aksarina in Pospelov et al. 1995)

Aperture elongate ovate in shape, adapical margin broadly rounded and slightly reflexed, lateral margin broadly arcuate (Figures 5F, 6G).

\section{Occurrence}

Maidiping Member of the Lower Cambrian Hungchunping Formation, at Gaoqiao of Emei, Sichuan, China.

\section{DISCUSSION}

During the last two decades, new merismoconchian material has been reported from the Lower Cambrian of Siberia and western Mongolia. Kundatoides perplexus Aksarina, 1995 is a strange fossil from the Lower Cambrian Atdabanian Stage of the Kiya River in the Kuznetsk Alatau, Siberia (Aksarina, in Pospelov et al. 1995). This species, known only from the holotype, was originally described as a tripartite organism consisting of a proarea, a median, and a body part. The proarea part protrudes forward. The median part with a pair of rounded lobes shows the top portion slightly projecting. A longitudinal, median, dorsal furrow divides the body part into two nearly symmetric parts, with some transverse ridges on each side of the median furrow; between the ridges there are more than four pairs of probable metameric oval muscle scars (Aksarina in Pospelov et al. 1995: 221, plate VI, figures 4-7; Figures 6B, 7 herein). Aksarina placed this oval mould into phylum, class and family unidentified, but she regarded it as resembling both trilobite and stenothecoid remains. However, the trilobite body is divided into three longitudinal segments, a central axis and two pleural regions, and three transverse segments: the cephalon, the thorax and the pygidium. The mould of Kundatoides perplexus is divided transversely into three parts, but no evidence could be found to subdivide the species into three longitudinal segments. In Kundatoides perplexus, only the body part is divided into two nearly symmetrical portions, and with more than four pairs of metameric transverse oval muscle (?) scars, in itself is enough to preclude inclusion of Kundatoides within the trilobites. In addition, there are several other characteristics, including the main morphological features of the cephalon, e.g., the glabella, the eye lobes and the suture lines, which are highly uncertain in Kundatoides perplexus. Stenothecoids are characterized by an asymmetric inequivalved, bivalved shell (Yochelson 1968, 1969, 2000; Aksarina and Pelman 1978; Koneva 1979; Yu 1996b). The mould of Kundatoides may represent a single shell because there are no morphological features to indicate that this fossil was ever bivalved. Furthermore, in some internal moulds of stenothecoids, the whole valve is divided into two asymmetric parts by a furrow (Aksarina 1968; Aksarina and Pelman 1978), while in Kundatoides, only the body part of the internal mould is divided into two nearly symmetric parts by a median dorsal furrow.

The observation that the mould of Kundatoides is divided into three unequal parts by two shell internal costae and with metameric pairs of muscle scars in the body part, lead the author to suggest that Kundatoides should be assigned to the Mollusca, as a possible merismoconch rather than to the trilobites or stenothecoids.

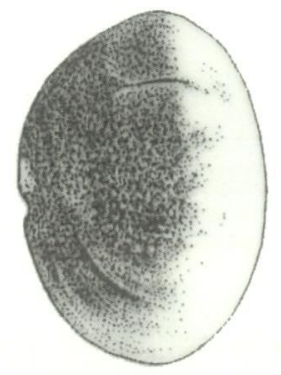

A

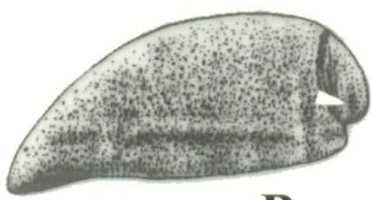

B

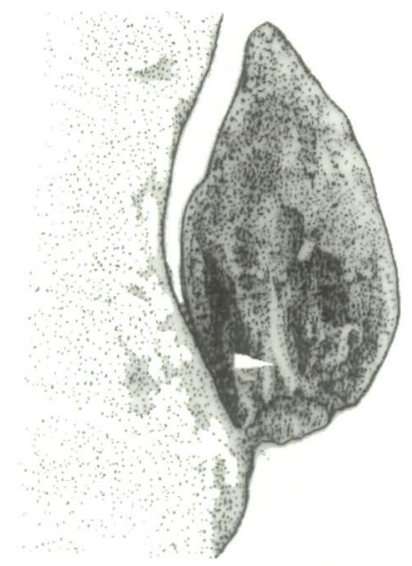

C

Figure 8 A-C. Davidella tommotica Zhegallo, 1996.A. dorsal view, x 33. Holotype Cat. no. 3302/ 1593. B. right lateral view, $x$ 30. C. Detail of anterior (white arrow) and posterior intersegmental furrows, x 130. Cat. no. 3302/ 1592. Lower Cambrian Tommotian Stage of W. Mongolia (after Zhegallo in Esakova and Zhegallo 1996). 

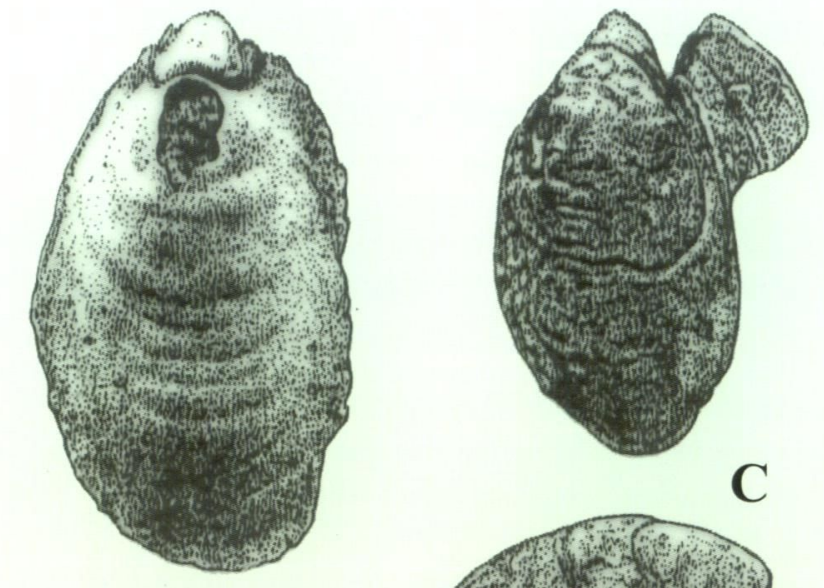

A

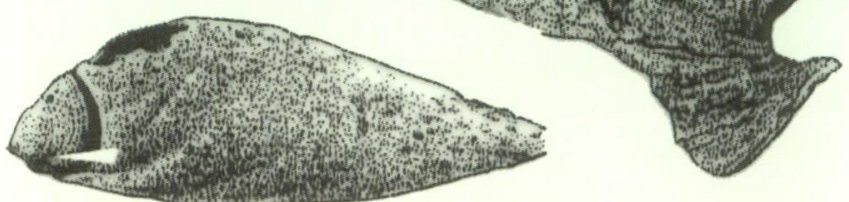

B

D

Figure 9 A-D. Merismoconcha? sp. Kerber, 1988. A. dorsal view, $x$ 21. B. lateral view, showing the anterior (white arrow) and posterior intersegmental furrows, x 20. Cat. no. UB114. C. dorsal view, $x 26$. D. lateral view, showing the anterior (white arrow) and posterior intersegmental furrows, $x 26$. Cat. no. UB110. Lower Cambrian "Herault" Limestone of Montagne Noire, France (after Kerber 1988).

Davidella, another interesting fossil, was erected by Zhegallo (1996) based on material from the Lower Cambrian Tommotian Stage of western Mongolia, with Davidella tommotica Zhegallo, 1996 as its type species. It was assigned to the family Enigmaconidae MacKinnon, 1985 of the Class Helcionelloida Peel, 1991. The generic diagnosis given (Zhegallo, in Esakova and Zhegallo 1996: 174) is as follows: "Tiny, low cap-shaped. Apex protruded to the apertural margin, with a good obliquely transverse pegma, which situated behind the apex and divided the dorsal side into two unequal parts. Aperture oval and simple. Some rugae can be seen". She further wrote (Zhegallo 1996: 174): "This genus differs from the Enigmaconus MacKinnon, 1985 in the more low and broad shell and in the different portion of the pegma, which is nearer to the apex".

Enigmaconus was erected by MacKinnon from a Middle Cambrian limestone lens of New Zealand in 1985, with Enigmaconus parvus MacKinnon, 1985 as its type species. Enigmaconus is characterized by a relatively broad, cone-shaped shell and with a well-developed transverse plate or pegma, dividing the shell into two unequal cavities. Its aperture is elongate-ovate. It is clear that in the overall shell features, apart from the distinctive shape of the shell, Enigmaconus has a pegma-like structure, whereas in Davidella the dorsal side of the internal mould bears two furrows, the anterior one thinner and more obscure than the posterior one (as shown on plate XXIII, figure $5 a, b$ by Zhegallo, in Esakova and Zhegallo 1996) (Figures $8 \mathrm{~B}, \mathrm{C})$.

Thus, Davidella is quite different in morphological features from Enigmaconus MacKinnon, but closely related to Merismoconcha sp., which was described by Kerber (1988) from the Lower Cambrian "Herault" Limestone of southern France. Kerber showed many photographs of Merismoconcha sp.. Among them, some complete specimens show two furrows (Kerber, 1988: 168, plate 6, figures $5 a, b, 9 a$, b; Figures $6 \mathrm{E}, 9 \mathrm{~A}-\mathrm{D})$, rather than one furrow as described by Kerber.

On the other hand, "Merismoconcha sp." of Kerber (1988) is somewhat similar to Merismoconcha multisegmentata, the type species of genus Merismoconcha. However, there are obviously differences between Kerber's Merismoconcha sp. and Merismoconcha multisegmentata by Yu (1979): 1) in Merismoconcha sp., the rostrate segment is very short and bluntly rounded, whereas in Merismoconcha multisegmentata, the rostrate segment is subtriangular in shape, strongly protruding forward to the anterior margin of the aperture; 2) in Merismoconcha sp., the second segment is convexly rounded and steeply sloping forward, whereas in Merismoconcha multisegmentata, the second segment is narrow, slightly concave and has a pair of radular muscle scars, which is large and simple, tadpole-like in shape (Figures 5A, B, D, E, G); 3) in Merismoconcha sp., the posterior intersegmental furrow is wide and deep, the central portion of the arc is curved, spreading gradually, sloping and bending forward to form a semicircular, narrowly marginal edge, then gradually sloping and reaching toward the anterolateral margin (Kerber, 1988, plate 6, figures 9a, b), but in Merismoconcha multisegmentata, the second segment is defined by fine, anterior and posterior intersegmental furrows, which converge in the middle part of both the left and right sides and with a convergent furrow, which gradually slopes toward the anterior margin of the aperture. From the above comparison, Merismoconcha multisegmentata is distinctly different from Merismoconcha sp. of Kerber, and Kerber's Merismoconcha sp. should be referred to another genus.

As previously noted (Yu 1984a, 1984b, 1987b, 1990), the general characters of the merismoconchs suggest a closer relationship to the classes Polyplacophora and Tergomya (or living Monoplacophora) than to other molluscs. They are also easily distinguished from shells of the superfamily Helcionelloidea, which was assigned to 
the Class Gastropoda by Kerber in 1988. Essentially, the Helcionelloidea are untorted molluscs (Peel 1991), which are strikingly different from the torted Gastropoda. The Helcionelloidea comprise a diversity of low to moderately cyrtoconic shells, unlike the merismoconchs' single, metameric shell, with two internal shell costae, that divide the bodycavity into three unequal segments.

With their single, bilaterally symmetrical shell, the merismoconchs are unlike those of the genus Halkieria Poulsen, 1967 (Runnegar, 1996), the shells which are very complex as shown by the generic diagnosis given by Conway Morris and Peel (1995): "Siculates form imbricating rows, each consisting of a fan-like array, apparently arising from a lobe. Imbricated cultrates flank lateral, anterior and posterior regions, increasing in size adaxially. Palmates arrayed in elongate rows, imbricating in posterior and adaxial direction. Shell convex dorsally, prominent growth lines and radial ornamentation. Anterior shell subquadrate, posterior shell more ovate, less convex and stronger radial ornamentation. Internal anatomy includes prominent rods beneath dorsal surface, running adaxially in an anterior direction, Straight gut, possibly with anterior feeding apparatus, subterminal anus." (Conway Morris and Peel 1995: 310).

\section{ACKNOWLEDGEMENTS}

Many thanks to Prof. Gerd Geyer of Universitat Murzburg, Germany; Prof. Feng Weimin of Nanjing Institute of Geology and Palaeontology, Chinese Academy of Sciences; Prof. Kenneth J. McNamara, Dr Mark S. Harvey and Mr George W. Kendrick of the Western Australian Museum for reviewing the manuscript and making valuable suggestions and appreciation for the use of museum facilities. Thanks also to Song Zhiyao, Chen Zhouqing and Mao Yongqiang for preparing the photographs; to Jill Ruse and Ouyang Qiaomin for preparing the figures.

\section{REFERENCES}

Aksarina, N. A. (1968). Probivalvia-A new class of the oldest Molluca. In: New data on the Geology and minerals of westem Siberia (Ocasional Paper) 3: $77-$ 86. (in Russian).

Aksarina, N. A. and Pelman, Yu. L. (1978). Cambrian brachiopods and bivalve mollusks of Siberia. Trudy Instituta Geologii i Geofiziki, AN SSSR 362: 180 pP. (in Russian).

Bengtson, S.(1992).Proterozoic and earliest Cambrian skeletal metazoans. In J.W.Schopf, and C. Klein (eds), The Proterozoic Biosphere: A multidisciplinary studr: 1017-1033. Cambridge University Press: Cambridge.

Caron, J. B., Scheltema, A., Schander, C. and Rudkin, D.
(2006). A soft-bodied molluse with radula from the Middle Cambrian Burgess Shale. Nature 442: 159-163.

Conway Morris, S. (1976). A new Cambrian lophophorate from the Burgess Shale of British Columbia. Palaeontology 19: 199-222.

Conway Morris, S. and Peel, J. S. (1995). Articulated halkieriids from the Lower Cambrian of North Greenland and their role in early protostome evolution. Philosophical Transactions of the Royal Society of London B 347: $305-358$.

Esakova, N. V. and Zhegallo, E. A. (1996). Biostratigraphy and fauna of Lower Cambrian of Mongolia. Trudy Sovmestnoj-Rossiysko-Mongol'skoj Paleontologichskoj Ekspeditsii 46: 1-214. (in Russian).

Fretter, V. (1937). The structure and function of the alimentary canal of some Polyplacophora (Mollusca). Transactions of the Royal Society of Edinburgh 59. Part I(4): 119-164.

Fedonkin, M. and Waggoner, B. M. (1997). The Late Precambrian fossil Kimberella is a mollusk-like bilaterian organism. Nature 388: 868-871.

Haszprunar, G. and Schaefer, K. (1996). Anatomy and phylogenetic significance of Micropilina arntzi (Mollusca, Monoplacophora, Micropilinidae fam. nov.). Acta Zoologica (Stockholm) 77: 315-334.

Hyman, L. (1967). Mollusca I. Invertebrates 6. 1-792. McGraw-Hill Book Company.

Kaas, P. and Van Belle, R. A. (1980). Catalogue of living Chitons (Mollusca: Polyplacophora). Dr. W. Backhuys, Publisher. Rotterdam, Netherlands.

Kerber, M. (1988). Mikrofossilien aus unterkambrischen Gesteinen der Montagne Noire, Frankreich. Palaeontographica Abt. A 202: 127-203.

Koneva, S. P. (1979). Stenothecoids and Inarticulate Brachiopods of the Lower Cambrian and Basal Middle Cambrian of Central Kazakhstan. Trudy Instituta Geologii AN SSR Kazakhstana: Alma Ata: 123 pp. (in Russian)

Lemche, H. and Wingstrand, K. G. (1959). The anatomy of Neoplina galatheae Lemche, 1957. Galathea Report 3: 9-71.

Mackinnon, D. I. (1985). New Zealand late Middle Cambrian molluses and the origin of Rostroconchia and Bivalvia. Alcheringa 9: 65-81.

Mclean, J.H. (1979). A new monoplacophoran limpet from the continental shelf off southern California. Contribution in Science of the Natural History Mustum of Los Angeles County 307: 1-19.

Peel, J.S. (1991). The Classes Tergomya and Helcionelloida, and early molluscan evolution. Gronlands Geologiske Undersogelse Bulletin 161: 11-65.

Pospelov, A. G., Pelman, Yu. L., Zhuravleva, I. T., Luchinina, V. A., Kuznetsova, V. G., Esakova, N. V., Ermak, V. V. and Aksarina, N. A. (1995). Biostratigraphy of the Kiya River Section. Anmales $d t^{\prime}$ Paleontologie (Vert.-Invert.) 81: 169-246.

Runnegar, B. (1996). Early evolution of the Mollusca: the fossil record. In j. Taylor (ed.), Origin and evolutionary radiation of the Mollusca: 77-87. Oxford University P'ress: Oxford.

Salvini-Plawen, L. v. (1985). Farly evolution and primitive groups, In E.R. Trueman and M. R. Clarke 
(eds), The Mollusca, vol. 10 (Evolution): 59-150. Academic Press: Orlando.

Salvini-Plawen, L. v. (1988). The structure and function of molluscan digestive systems. In E. R. Trueman and M. R. Clarke (eds), The Mollusca, vol. 11. Form and Function 301-379. Academic Press, London.

Schaefer, K. and Haszprunar, G. (1996). Anatomy of Laevipilina antractica, a Monoplacophoran limpet (Mollusca) from Antarctic Waters. Acta Zoologica (Stockholm) 77(4): 295-314.

Scheltema, A. H. (1988). Ancestors and descendants: relationships of the Aplacophora and Polyplacophora. American Malacological Bulletin 6: 57-68.

Sepkoski, J., Jr. (2002). A compendium of fossil marine animal genera. Bulletin of American Palaeontology 363.

Waren, A. and Hain, S. (1992). Laevipilina antarctica and Micropilina arntzi, two new monoplacophorans from the Antarctic. The Veliger 35: 165-176.

Waren, A. and Gofas, S. (1996). A new species of Monoplacophora, redescription of the genera Veleropilina and Rokopella, and new information on three species of the class. Zoologica Scripta 25(3): 215232.

Wingstrand, K. G. (1985). On the anatomy and relationships of recent Monoplacophora.Galathea Report 16: 7-94.

Yin Jicheng, Ding Lianfang, He Tinggui, Li Shilin and Shen Lijuan (1980). The palaeontology and sedimentary environment of the Sinian System in Emei-Ganluo areas, Sichuan. 231 pp. The Sichuan People's Publishing House, China.

Yochelson, E. L. (1968). Stenothecoida, a proposed new class of Cambrian Mollusca. International Palaeontological Union, Prague, Czechoslovakia, Abstracts, August 20-27, 1968: 34.

Yochelson, E. L. (1969). Stenothecoida, a proposed new class of Cambrian Mollusca. Lethaia 2: 49-62.

Yochelson, E. L. (2000). Concerning the concept of extinct classes of Mollusca: or what may/may not be a class of mollusk. American Malacological Bulettin 15: 195202.

Yu Wen (1979). Earliest Cambrian monoplacophorans and gastropods from western Hubei with biostratigraphical significance. Acta Palaeontologica Sinica 18: 233-270 (in Chinese with English summary).
Yu Wen (1983). A study on the earliest Cambrian molluscan faunas of Yangtze Region in China. Kexue Tongbao (Chinese Science Bulletin) 28: 1572.

Yu Wen (1984a). Early Cambrian molluscan faunas of Meishucun Stage with special reference to Precambrian-Cambrian boundary. Academia Sinica Developments in Geoscience, Contribution to $27^{\text {h }}$ International Geological Congress, 1984, Moscow: 2135. Science Press: Beijing.

Yu Wen (1984b). On merismoconchids. Acta Palaeontologica Sinica 23: $432-446$ (in Chinese with English summary).

Yu Wen (1987a). New molluscan materials of the Tethys. In K.G. McKenzie (ed.), Proceedings of the International Symposium on the Shallow Tethys 2: 51-59. A.A. Balkema, Rotterdam.

Yu Wen (1987b). Yangtze micromolluscan fauna in Yangtze Region of China with notes on PrecambrianCambrian boundary. In Nanjing Institute of Geology and Palaeontology, Academia Sinica (ed.), Stratigraphy and Palaeontology of Systemic Boundaries in China. Precambrian-Cambrian Boundary, vol. 1: 19-344. Nanjing University Publishing House: Nanjing.

Yu Wen (1988). New advances in the study of earliest Cambrian molluscan fauna of China. Kexue Tongbao (Chinese Science Bulletin) 33: 1555-1557.

Yu Wen (1989). Did the shelled mollusks evolve from univalved to multivalved forms or vice versa? Chinese Academy of Sciences Developments in Geoscience, Contribution to $28^{\text {th }}$ International Geological Congress, 1989, Washington, D.C.: 235244. Science Press: Beijing.

Yu Wen (1990). The first radiation of shelled mollusks. Palaeontologia Cathayana 5: 139-170.

Yu Wen (1996a). Yangtze micromolluscan fauna and its significance. In J.E. Repetsky (ed.), Sixth North American Paleontological Convention, Abstracts of Papers, Smithsonian Institutions, Washington, D.C. The Paleontological Society Special Publication 8: 433.

Yu Wen (1996b). Early Cambrian stenothecoid mollusks from China. Records of the Western Australian Museum 18: 209-217.

Yu Wen (2005). The bivalve Yangtzedonta is not the brachiopod Xianfengella. Acta Geologica Sinica 79: 770-776.

Manuscript accepted 30 July 2007. 